\title{
Effects of a beetroot juice with high neobetanin content on the early-phase insulin response in healthy volunteers
}

\author{
Peter C. Wootton-Beard ${ }^{1}$, Kirsten Brandt ${ }^{2}$, David Fell ${ }^{3}$, Sarah Warner ${ }^{1,2}$ and Lisa Ryan ${ }^{1,4} *$ \\ ${ }^{1}$ Functional Food Centre, Oxford Brookes University, Gipsy Lane, Oxford OX3 OBP, UK \\ ${ }^{2}$ Human Nutrition Research Centre, School of Agriculture and Rural Development, Newcastle University, Newcastle upon Tyne NE1 7RU, UK \\ ${ }^{3}$ Cell Systems Modelling Group, Oxford Brookes University, Gipsy Lane, Oxford OX3 OBP, UK \\ ${ }^{4}$ Department of Nutrition and Dietetics, Monash University, Faculty of Medicine, Nursing and Health Sciences, 264 Ferntree Gully Road, Vic \\ 3168, Australia
}

(Received 2 September 2013 - Final revision received 13 February 2014 - Accepted 14 February 2014)

Journal of Nutritional Science (2014), vol. 3, e9, page 1 of 9

doi:10.1017/jns.2014.7

Abstract

Produce rich in phytochemicals may alter postprandial glucose and insulin responses by interacting with the pathways that regulate glucose uptake and insulin secretion in humans. The aims of the present study were to assess the phytochemical constituents of red beetroot juice and to measure the postprandial glucose and insulin responses elicited by either $225 \mathrm{ml}$ beetroot juice (BEET), a control beverage matched for macronutrient content (MCON) or a glucose beverage in healthy adults. Beetroot juice was a particularly rich source of betalain degradation compounds. The orange/yellow pigment neobetanin was measured in particularly high quantities (providing $1.3 \mathrm{~g}$ in the $225 \mathrm{ml}$ ). A total of sixteen healthy individuals were recruited, and consumed the test meals in a controlled single-blind cross-over design. Results revealed a significant lowering of the postprandial insulin response in the early phase $(0-60$ $\min )(P<0.05)$ and a significantly lower glucose response in the $0-30$ min phase $(P<0.05)$ in the BEET treatment compared with MCON. Betalains, polyphenols and dietary nitrate found in the beetroot juice may each contribute to the observed differences in the postprandial insulin concentration.

Key words: Postprandial glycaemia: Phytochemicals: Betalains

Polyphenols including flavonoids, phenolic acids, proanthocyanidins and tannins have been suggested to be able to modify postprandial glycaemia ${ }^{(1,2)}$. Polyphenols may alter glycaemia by inhibiting carbohydrate $(\mathrm{CHO})$ digestion, reducing $\mathrm{CHO}$ absorption in the intestines, stimulation of insulin release from pancreatic $\beta$-cells, modulation of hepatic glucose output, activation of insulin receptors, or modulation of glucose uptake in insulin-sensitive cells ${ }^{(3)}$. Isoflavonoids (soya), condensed tannins such as epigallocatechin-3-gallate from tea, phenolic acids (coffee), resveratrol (grapes), apple flavonoids, terpenoids (herbs), as well as cranberry, strawberry and blueberry anthocyanin metabolites have been studied for their antihyperglycaemic effects (for a review, see Hanhineva et al. ${ }^{(2)}$ ).
The development of dietary components that positively influence postprandial glycaemia is of upmost importance because of their potential to reduce the impact of type 2 diabetes. The global incidence of type 2 diabetes is predicted to reach 360 million cases by the year $2030^{(4)}$, clearly articulating the need for investigations into the anti-hyperglycaemic effects of plant foods. The release and uptake of insulin are central to the absorption and transport of glucose from an ingested meal. Meals containing a large amount of $\mathrm{CHO}$ elicit a proportionate rise in plasma glucose that stimulates a rapid rise in blood insulin, termed insulinaemia. Repeated bouts of hyperglycaemia and hyperinsulinaemia may result in insulin resistance or transient hypoglycaemia owing to the rapid rise and

Abbreviations: BEET, beetroot beverage; CHO, carbohydrate; GLUC, glucose beverage; iAUC, incremental AUC; MCON, matched control beverage; sAUC, segmental AUC.

* Corresponding author: Dr Lisa Ryan, email l.ryan@monash.edu 
fall of blood glucose. Insulin resistance is central to the development of type 2 diabetes and is one pillar of the metabolic syndrome, diseases that place a high economic burden on global societies ${ }^{(5)}$. Polyphenols and related compounds have been described to reduce both postprandial hyperglycaemia and prevent reactive hyperinsulinaemia by reducing the digestion, absorption and transport of glucose ${ }^{(6-9)}$.

Beetroot juice has received attention in the scientific literature recently, particularly due to its nitrate content ${ }^{(10)}$. Dietary nitrate is converted to nitrite by anaerobic bacteria in the saliva and subsequently to $\mathrm{NO}$ in the stomach, which complements endogenous NO production from L-arginine ${ }^{(11)}$. Excess nitrate has been linked to gastrointestinal/gastro-oesophageal cancers in adults $^{(12)}$ and to methaemoglobinaemia in infants ${ }^{(13)}$. Nitrate is consumed in the diet primarily from processed meats, fish and from vegetable sources. The beneficial effects of nitrate from plant sources have been reviewed in detail ${ }^{(14)}$ and, as such, consumption of nitrate-rich vegetables is encouraged, whilst a reduction in processed meat is advised to ameliorate potential negative consequences. However, nitrate is only one component of the traditional root vegetable beetroot, and other investigations have sought to determine its phytochemical composition ${ }^{(15-17)}$. Beetroot contains a number of compounds including phenolic acids, flavonoids and betalains ${ }^{(15)}$, and beetroot juice has a high total antioxidant capacity and total polyphenol content as measured by the Folin-Ciocalteu method $^{(16,17)}$. Furthermore, in terms of available $\mathrm{CHO}$, beetroot is composed of approximately $90 \%$ sucrose. Beetroot juice is therefore an interesting food model to investigate any influence of its bioactive components on the glycaemic response, either by direct inhibition of glucose uptake or by indirect action affecting insulin sensitivity. The aims of the present study were to identify and measure the phytochemical constituents of a commercial beetroot juice product, and to quantify and compare the glucose and insulin responses to a total available $\mathrm{CHO}$ intake of $50 \mathrm{~g}$, delivered as either 225 $\mathrm{ml}$ of beetroot juice, or $225 \mathrm{ml}$ of a control beverage matched for macronutrient composition or a positive control of $225 \mathrm{ml}$ of a glucose-only beverage. Beetroot juice and its components have not been studied in this context before. Their major components, betalains, bear certain structural similarities to anthocyanins that have been shown to elicit alterations in blood glucose and insulin responses. It is, therefore, important to consider the potential impact of betalains as beetroot is widely available, easy to cultivate, pleasant tasting and relatively cheap for manufacturers and consumers alike.

\section{Experimental methods}

Determination of nitrate, nitrite, betalain and phenolic content of the beetroot juice

Nitrate and nitrite concentrations were measured in duplicate

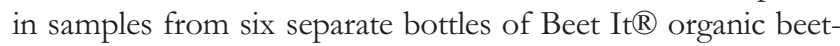
root juice with lemon by GC-MS as isotope dilution after derivatisation with 2,3,4,5,6-pentafluorobenzyl bromide (PFB-Br) according to Tsikas $^{(18)}$ with minor modifications. Briefly, known concentrations of $\left[{ }^{15} \mathrm{~N}\right]$ nitrate and $\left[{ }^{15} \mathrm{~N}\right]$ nitrite as internal standards were added to the beetroot juice. Then $200 \mu \mathrm{l}$ spiked sample, $800 \mu \mathrm{l}$ acetone and $20 \mu \mathrm{l}$ PFB-Br were mixed and incubated for $20 \mathrm{~min}$ at $50^{\circ} \mathrm{C}$ in a sealed tube, after which the acetone was evaporated under an $\mathrm{N}_{2}$ stream. A quantity of $2 \mathrm{ml}$ toluene and $1 \mathrm{ml}$ water was added and shaken for $1 \mathrm{~min}$. After phase separation, the upper (toluene) phase was analysed on a GC-MS (Shimadzu Corporation) with an Optima 17 column (15 $\mathrm{m}, 0.25 \mathrm{~mm}$ internal diameter, $0.25 \mu \mathrm{m}$ film thickness), using negative-ion chemical ionisation, splitless mode, $\mathrm{He}(70 \mathrm{kPa})$ as column carrier, methane $(200 \mathrm{~Pa})$ as reagent. Initial column temperature was $70^{\circ} \mathrm{C}$, held for $1 \mathrm{~min}$, then increased $30^{\circ} \mathrm{C} / \mathrm{min}$ to $280^{\circ} \mathrm{C}$, with electron energy $230 \mathrm{eV}$ and electron current $300 \mu \mathrm{A}$, ion source $180^{\circ} \mathrm{C}$, interface $280^{\circ} \mathrm{C}$ and injector $200^{\circ} \mathrm{C}$. $\left[{ }^{15} \mathrm{~N}\right]$ and $\left[{ }^{14} \mathrm{~N}\right]$ nitrate were measured at $m / z .63$ and 62 , respectively, with retention time (RT) $3.2 \mathrm{~min},\left[{ }^{15} \mathrm{~N}\right]$ and $\left[{ }^{14} \mathrm{~N}\right]$ nitrite at $\mathrm{m} / \mathrm{z}$ 47 and 46, respectively, with RT $3.4 \mathrm{~min}$.

Betalains and phenolic compounds were measured using the method of Nemzer et al. ${ }^{(19)}$ on a Shimadzu Prominence HPLC with a Luna C-18 analytical column $(25 \mathrm{~cm}, 3 \mathrm{~mm}$ internal diameter, $5 \mu \mathrm{m}$ particle size; Phenomenex) and an SPDM20A diode array detector (Shimadzu). Solvents were B, acetonitrile; and A, $2 \%$ formic acid in water. The gradient was $3 \% \mathrm{~B}$ at $0 \mathrm{~min}, 16 \% \mathrm{~B}$ at $17 \mathrm{~min}, 50 \% \mathrm{~B}$ at $30 \mathrm{~min}$, $100 \% \mathrm{~B}$ at $32-35 \mathrm{~min}$ and $3 \% \mathrm{~B}$ at 35-45 min with $0.5 \mathrm{ml} / \mathrm{min}$ flow rate, $35^{\circ} \mathrm{C}$ column temperature and $10 \mu \mathrm{l}$ injection volume. Peaks were recorded at $538 \mathrm{~nm}$ (betanins), $480 \mathrm{~nm}$ (betaxanthins and neobetanin), $505 \mathrm{~nm}$ (decarboxylated betanins) and $320 \mathrm{~nm}$ (phenolic compounds). Phenolic compounds were quantified at $320 \mathrm{~nm}$ rather than at the maximum wavelength for each compound; this was for practical reasons since most of them were not specifically identified, and this is a commonly used wavelength to measure phenolic compounds. Quantification of betanin, isobetanin, 17-decarboxyisobetanin and neobetanin was done by comparison with standards isolated by semi-preparative HPLC from the beetroot juice using the same equipment and solvents, on a Develosil ODS-HG-5 HPLC column (RP-18, $250 \times 20 \mathrm{~mm}$ internal diameter), $5 \mu \mathrm{m}$ particle size. The gradient was $3 \%$ $\mathrm{B}$ at $0 \mathrm{~min}, 16 \% \mathrm{~B}$ at $20 \mathrm{~min}, 50 \% \mathrm{~B}$ at $40 \mathrm{~min}, 100 \% \mathrm{~B}$ at $47 \mathrm{~min}$ until $60 \mathrm{~min}$, with $3 \mathrm{ml} / \mathrm{min}$ flow rate, $35^{\circ} \mathrm{C}$ column temperature and $400 \mu \mathrm{l}$ injection volume. Quantification of flavonoids and phenolic acids was done by comparison with authentic standards of rutin and chlorogenic acid, respectively, measured at $320 \mathrm{~nm}$. In all, four peaks had UV spectra that matched typical flavonoid spectra and eighteen peaks were similar to phenolic acids.

\section{Subjects and study design}

A group of sixteen healthy adults (six male and ten female) were recruited by poster for the present study. Subject characteristics are provided in Table 1 . The present study was conducted according to the guidelines laid down in the Declaration of Helsinki and all procedures involving human subjects/patients were approved by the Oxford Brookes University Ethics Committee (110553). Written informed consent was obtained from all subjects. Participants were asked to 
Table 1. Participant characteristics (Mean values and standard deviations)

\begin{tabular}{lll}
\hline & Mean & SD \\
\hline Age (years) & 27 & 5 \\
Height $(\mathrm{cm})$ & 172.4 & 8.6 \\
Weight $(\mathrm{kg})$ & 69.2 & 11.7 \\
BMl $\left(\mathrm{kg} / \mathrm{m}^{2}\right)$ & 23.3 & 2.8 \\
Fat $(\%)$ & 23.0 & 7.0 \\
Physical activity index & & \\
$\quad$ Work & 2.44 & 0.25 \\
$\quad$ Sport & 3.71 & 2.06 \\
$\quad$ Leisure & 3.19 & 0.49 \\
Polyphenol intake (g/d) & 1.93 & 0.59 \\
\hline
\end{tabular}

visit the laboratory on three separate occasions. Before the first visit each participant was asked to complete a confidential health questionnaire pertaining to their medical history, a habitual physical activity questionnaire, and a modified FFQ designed to provide an estimate of their habitual polyphenol intake. Each visit was separated by no less than $48 \mathrm{~h}$. At the start of each visit anthropometric measurements were taken and adherence to a $12 \mathrm{~h}$ fast, abstinence from caffeine, alcohol and intense physical activity as well as adequate hydration were assured verbally. Participants were excluded if they had type 2 diabetes or a fasting blood glucose measure of $>6 \cdot 1 \mathrm{mmol} / \mathrm{l}$. Participants provided two baseline finger capillary samples separated by $5 \mathrm{~min}$ before consuming the test beverage. In a randomised, single-blind, cross-over design, three test beverages were provided to each subject.

\section{Study protocol}

The first beverage (BEET) consisted of $225 \mathrm{ml}$ Beet It ${ }^{\circledR}$ organic beetroot juice with lemon $(<2 \%$ ) (James White Drinks Ltd) providing a total of $50 \mathrm{~g}$ available CHO. The second beverage (MCON) consisted of a matched control drink $(225 \mathrm{ml})$ containing sucrose, fructose, glucose, pea protein isolate, inulin and sodium chloride providing a total of $50 \mathrm{~g}$ available CHO (the precise composition of BEET and MCON are shown in Table 2). The third beverage (GLUC) contained $50 \mathrm{~g}$ available $\mathrm{CHO}$ as glucose $(225 \mathrm{ml})$. On each test day postprandial finger-prick blood samples were taken at 5, 15, 30, 45, 60, 90, 120 and $150 \mathrm{~min}$ (time points T5, T15, T30, T45, T60,
T90, T120 and T150, respectively) to measure both blood glucose $(5 \mu \mathrm{l})$ and plasma insulin $(300 \mu \mathrm{l})$ using a Unistik 3 singleuse lancing device (Owen Mumford). Glucose concentration was measured using a Hemocue Glucose 201+ analyser (HemoCue Limited) calibrated to plasma equivalent glucose concentrations. For each meal the incremental AUC (iAUC) was calculated geometrically ignoring the area below the baseline ${ }^{(20)}$. Plasma samples were analysed for insulin using a radioimmunoassay on an automated immunoanalyser (Cobas E411; Roche Diagnostics). Plasma was separated from whole blood by centrifugation (4000 rpm for $10 \mathrm{~min}$ ) and stored at $-40^{\circ} \mathrm{C}$ for no more than 1 month. The procedures used to measure the glucose and insulin responses were adapted from those described by Brouns et al. ${ }^{(21)}$ and Wolever $^{(22)}$ and were in line with the recommendations of the $\mathrm{FAO} / \mathrm{WHO}^{(20)}$.

FFQ were analysed using the Phenol-Explorer database ${ }^{(23)}$ to estimate habitual polyphenol intake. The Phenol-Explorer database lists food polyphenol content according to a number of common methods. In this instance the values obtained by the Folin-Ciocalteu method were used, as these are available for the highest number of foods, allowing for the best representation of habitual intake for this type of enquiry. Habitual polyphenol intake $(\mathrm{g} / \mathrm{d})$ is displayed in Table 1. Habitual physical activity was assessed using the physical activity index proposed by Baecke et al. ${ }^{(24)}$. Based on a scale, proportionate to the levels of physical exertion required to perform the activity, each question in a standard questionnaire is given a value between 1 and 5, with the exception of sport and exercise which is calculated as a product of the average energy used for the activity (MJ), intensity of performance and the time spent performing. Physical activity is displayed in Table 1.

\section{Insulin sensitivity}

An index of insulin sensitivity $\left(\mathrm{S}_{\mathrm{I}}\right)$ was calculated using the oral glucose minimal model reported by Burattini et al. ${ }^{(25)}$ in their investigation of insulin action and secretion that used a model based on the oral glucose tolerance test. It is an amalgamation of the classic minimal model of glucose kinetics coupled with an equation describing the rate of appearance of glucose into the circulation ${ }^{(26)}$. The following equation

Table 2. Nutrient composition of the beetroot juice beverage (BEET), matched control beverage (MCON) and glucose control beverage (GLUC)

\begin{tabular}{|c|c|c|c|}
\hline Nutrient & BEET (per 225 ml)* & MCON (per 225 ml) & GLUC (per $225 \mathrm{ml}$ ) \\
\hline \multicolumn{4}{|l|}{ Energy } \\
\hline kJ & 931 & 943 & 941 \\
\hline kcal & 223 & 225 & 225 \\
\hline Reduced N (g) & 0.91 & 0.91 & - \\
\hline Fat $(\mathrm{g})$ & 0.00 & 0.08 & - \\
\hline Carbohydrate (g) & $50 \cdot 4$ & $50 \cdot 4$ & $50 \cdot 0$ \\
\hline Of which sucrose (g) & 39.35 & $39 \cdot 35$ & - \\
\hline Of which glucose $(\mathrm{g})$ & 4.77 & 4.77 & $50 \cdot 0$ \\
\hline Of which fructose $(\mathrm{g})$ & $5 \cdot 13$ & $5 \cdot 13$ & - \\
\hline Fibre & $1 \cdot 13$ & $1 \cdot 13$ & - \\
\hline $\mathrm{Na}(\mathrm{mg})$ & 117 & 117 & - \\
\hline
\end{tabular}

* Data from Eurofins Testing Ltd (unpublished results) on the carbohydrate composition of Beet It@ organic beetroot juice with lemon. 
describes the model:

$\mathrm{S}_{\mathrm{I}}=\frac{\mathrm{f} \times \frac{D}{W} \times \frac{\operatorname{AUC}(\Delta \mathrm{G}(t) / \mathrm{G}(t))}{\operatorname{AUC}(\Delta \mathrm{G}(t))}-\mathrm{GE} \times \operatorname{AUC}(\Delta \mathrm{G}(t) / \mathrm{G}(t))}{\operatorname{AUC}(\Delta \mathrm{I}(t))}$,

where AUC denotes the AUC of the quantities in parentheses during the total time course $(t) 0-(t) 150$, and $\Delta \mathrm{G}(t)$ and $\Delta \mathrm{I}(t)$ are glycaemia and insulinaemia above fasting values. GE is glucose effectiveness and $\mathrm{f}$ is the fraction of glucose appearing in the systemic circulation; values of $3.7 \times 10^{-2} \mathrm{~min} / \mathrm{dl}$ per $\mathrm{kg}$ and $0 \cdot 87$, respectively, are used in accordance with those reported by Burattini et al. ${ }^{(25)} \cdot \frac{D}{W}$ is the dose of glucose per $\mathrm{kg}$ body weight and is calculated individually for each subject.

\section{Statistical analyses}

A mixed-model ANOVA with two factors ('meal' and 'time') was conducted but the assumed covariance matrix was discovered to be significantly different from the observed matrix. Therefore, comparisons of the data were made by repeated-measures ANOVA for glucose and insulin at each time point. Main effects were compared for the withinsubjects factor 'meal' and corrected with a Bonferroni adjustment. Both iAUC and segmental AUC (sAUC) were also calculated and compared using repeated-measures ANOVA. Statistical power was calculated in consultation with the statistics department at Oxford Brookes University and is based on the mean and standard deviation of pilot data using similar conditions and participants. A minimum detectable difference of $10 \%$ was chosen for insulin, as the spread of data from T0 to T150 is quite large and insulin is the primary outcome measure. Power was calculated using an online calculator for cross-over studies whereby the outcome is a measurement. The results showed that a power of 0.9 would be achieved at a significance level of $P<0.05$ using sixteen participants.

\section{Results}

\section{Phytochemical composition}

Average nitrate concentration was $4.40 \mathrm{~g} / 1$, ranging from 3.03 to $5.24 \mathrm{~g} / 1$ in six individual bottles, with an average relative SD within samples of $2.5 \%$. Average nitrite concentration was
$2.34 \mathrm{mg} / \mathrm{l}$, ranging from 2.23 to $2.55 \mathrm{mg} / \mathrm{l}$ in individual bottles, with an average relative standard deviation within samples of $2.0 \%$. There was no correlation between nitrate and nitrite concentrations when comparing individual bottles $\left(R^{2} 0 \cdot 147\right.$; $P=0.781)$. Values for the sum of betalains, betaxanthins, flavonoids, phenolic acids and some individual betalains are shown in Table 3. The beetroot juice was a particularly rich source of the orange/yellow pigment neobetanin $(1263 \mathrm{mg}$ per $225 \mathrm{ml}$ ) and contained a total of $129 \mathrm{mg}$ polyphenolic compounds per $225 \mathrm{ml}$. Analysis of the $\mathrm{CHO}$ content of the beetroot juice showed that the composition was $90 \%$ sucrose, $5 \%$ glucose, $4 \%$ fructose with minor amounts of maltose and lactose $(<0.1 \mathrm{~g}$ per $100 \mathrm{~g})$. Crude protein content was $2.53 \mathrm{~g}$ per $100 \mathrm{~g}$, and total fibre was $<0.5 \mathrm{~g}$ per $100 \mathrm{~g}$. The value for neobetanin was adjusted for a low recovery $(47.5 \%)$ measured by quantification of a purified sample with analytical HPLC and compared with the spectrophotometric value. The recovery was even less during semi-preparative HPLC.

\section{Glycaemic response}

No significant differences were observed between the MCON and BEET beverages during the total glycaemic response (iAUC). Both the MCON and BEET conditions produced a significantly lower glycaemic response than the GLUC condition $(P<0 \cdot 05)$, as expected (Table 4). Analysis of the AUC by segment (sAUC) revealed a significantly lower glycaemic response for BEET compared with MCON in the 0-30 min segment $(P<0 \cdot 05)$ (Fig. 1). BEET was also significantly lower than GLUC in the $0-30 \mathrm{~min}$ and $0-45 \mathrm{~min}$ segments. In the 0-60 min segment BEET remained significantly lower than GLUC $(P<0 \cdot 05)$. Both MCON and BEET were significantly lower than GLUC $(P<0 \cdot 05)$ in the $0-90$ min segment. Data were also analysed by time point. Significant differences between the experimental conditions are shown in Table 4. BEET was significantly lower $(P<0.05)$ than MCON at T5. BEET was significantly lower $(P<0 \cdot 05)$ than GLUC at T30, and BEET and MCON were both significantly lower than GLUC at T45, T60 and T90.

\section{Insulin response}

iAUC analysis revealed no significant difference between the three conditions for insulin response (Table 4). The data

Table 3. Phytochemical composition of the beetroot juice beverage

(Mean values with their standard errors $(n 6)$, and relative standard deviations)

\begin{tabular}{llll}
\hline & \multicolumn{2}{c}{ Concentration (mg/l) } & \\
\cline { 2 - 3 } Compound & Mean & SEM & Relative SD (\%) \\
\hline Sum of betaxanthins (yellow native pigments) & 14.6 & 1.1 & 18 \\
Sum of betanins (purple native pigments) & 215 & 23 & 26 \\
Sum of betanin degradation products & 5975 & 68 & 2.8 \\
Sum of flavonoids (rutin equivalents) & 323.14 & 0.69 & 0.52 \\
Sum of phenolic acids (chlorogenic acid equivalents) & 248.2 & 4.6 & 4.5 \\
Betanin & 83.7 & 8.0 & 23 \\
Isobetanin & 131 & 15 & 28 \\
17-Decarboxy-isobetanin & 22.56 & 0.40 & 4.3 \\
Neobetanin & 5617 & 65 & 2.9 \\
\hline
\end{tabular}


Table 4. Incremental AUC analysis for glucose and insulin (Mean values and standard deviations, $n$ 16)

\begin{tabular}{|c|c|c|c|c|c|c|}
\hline \multirow[b]{2}{*}{ Time (min) } & \multicolumn{2}{|c|}{ MCON } & \multicolumn{2}{|c|}{ BEET } & \multicolumn{2}{|c|}{ GLUC } \\
\hline & Mean & SD & Mean & $\mathrm{SD}$ & Mean & SD \\
\hline \multicolumn{7}{|c|}{ Glycaemic response } \\
\hline 5 & $2 \cdot 7$ & 1.9 & 1.4 & $1 \cdot 3^{*}$ & 1.3 & 1.5 \\
\hline 15 & $15 \cdot 4$ & $7 \cdot 0$ & $10 \cdot 7$ & $5 \cdot 7$ & $14 \cdot 1$ & 7.4 \\
\hline 30 & $28 \cdot 3$ & $15 \cdot 9$ & $22 \cdot 0$ & $10 \cdot 0 \dagger$ & 33.9 & $12 \cdot 8$ \\
\hline 45 & $15 \cdot 5 \dagger$ & $14 \cdot 6$ & 13.5 & $10 \cdot 2 \dagger$ & 28.7 & $17 \cdot 8^{*}$ \\
\hline 60 & $3.4 \dagger$ & $8 \cdot 3$ & $5 \cdot 6$ & $7.2 \dagger$ & $17 \cdot 9$ & $13 \cdot 7^{\star}$ \\
\hline 90 & $1.6 \dagger$ & 3.9 & 3.9 & $6 \cdot 7 \dagger$ & $16 \cdot 8$ & $16 \cdot 3^{*}$ \\
\hline 120 & 0.7 & 1.9 & 1.6 & $3.7 \dagger$ & $3 \cdot 6$ & 5.7 \\
\hline 150 & 1.4 & $2 \cdot 3$ & 1.3 & $2.5 \dagger$ & 0.2 & 0.5 \\
\hline Total & 69 & 44 & 60 & 33 & 116 & 60 \\
\hline \multicolumn{7}{|c|}{ Insulin response } \\
\hline 5 & 63 & 57 & 35 & 27 & 37 & 34 \\
\hline 15 & $354 \dagger$ & 207 & 227 & $144^{*}$ & 222 & 133 \\
\hline 30 & $635 \dagger$ & 334 & 444 & 346 & 465 & 349 \\
\hline 45 & 397 & 292 & 313 & 268 & 408 & 369 \\
\hline 60 & 166 & 116 & 173 & 148 & 253 & 227 \\
\hline 90 & 82 & 108 & 170 & 177 & 216 & 289 \\
\hline 120 & 8 & 21 & 43 & $94^{*}$ & 55 & 119 \\
\hline 150 & 5 & 19 & 4 & 14 & 5 & 13 \\
\hline Total & 1694 & 842 & 1409 & 959 & 1661 & 1109 \\
\hline
\end{tabular}

MCON, matched control beverage; BEET, beetroot beverage; GLUC, glucose beverage.

* Mean value was significantly different from that of the MCON condition $(P<0.05)$.

† Mean value was significantly different from that of the GLUC condition $(P<0.05)$.

were separated into the $0-30,0-45,0-60$ and $0-90 \mathrm{~min}$ segments and further analysed (Fig. 2). The BEET condition elicited a significantly lower insulin response in the 0-30, 0-45 and $0-60$ min segments $(P<0.05$ for each) compared with MCON. The data were also analysed by time point (Table 4). A non-significant, lower insulin response was observed for BEET compared with MCON at T5 ( $P=$ 0.08), which reached significance at T15 $(P<0.05)$ and remained evident, although not significant, at T30 $(P=0.09)$. The BEET condition was shown to elicit a significantly higher insulin response than MCON at T120 (P<0.05), although the actual values are relatively small.

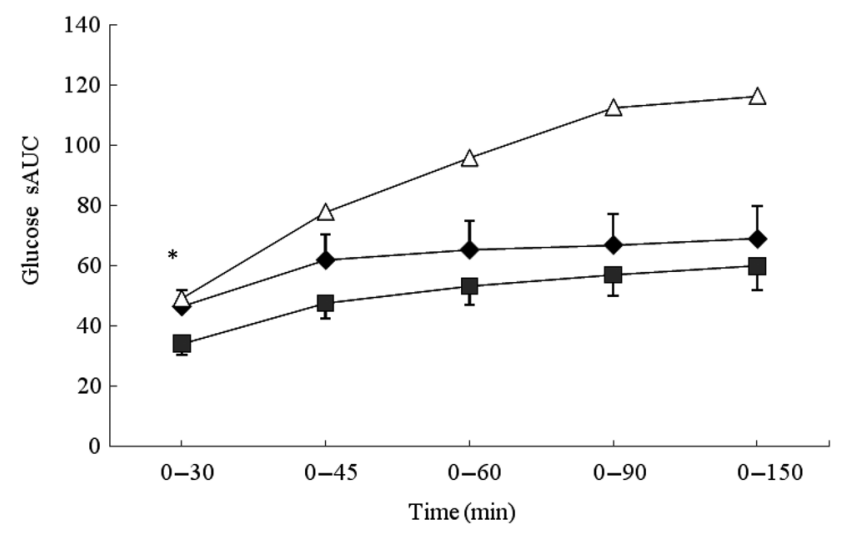

Fig. 1. Segmental areas under the blood glucose response curve (sAUC). Values are means ( $n$ 16), with standard deviations represented by vertical bars. For clarity, negative error bars are shown for the beetroot beverage (BEET; $\square)$ and positive error bars are displayed for the matched control beverage (MCON; $\downarrow)$. Error bars are not displayed for the glucose beverage (GLUC; $\Delta$ ) but were comparable in magnitude. * Mean value for BEET was significantly different from that for $\operatorname{MCON}(P<0.05)$.

\section{Physical activity and polyphenol consumption}

The mean physical activity index for this cohort was $3 \cdot 11$ (SD 0.75). Individually, the work index was 2.44 (SD 0.25), the sport index was 3.71 (SD 2.06) and the leisure index was 3.19 (SD 0.49). These values indicate a recreationally active cohort. Polyphenol intake for this cohort was 1925 (SD 592) $\mathrm{mg} / \mathrm{d}$ with a range $853-2807 \mathrm{mg} / \mathrm{d}$. This suggests a cohort with a relatively high habitual intake of polyphenols.

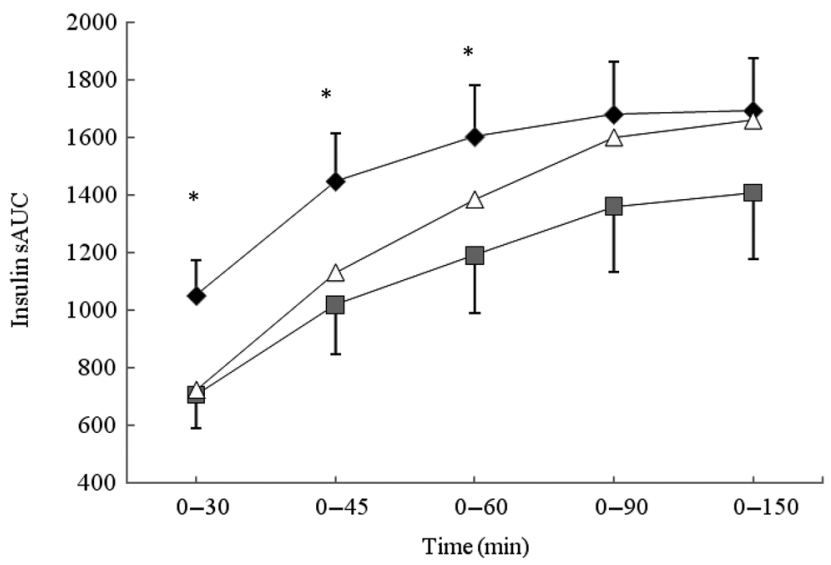

Fig. 2. Segmental areas under the blood insulin response curve (sAUC). Values are means ( $n$ 16), with standard deviations represented by vertical bars. For clarity, negative error bars are shown for the beetroot beverage (BEET; $\mathbf{\square})$ and positive error bars are displayed for the matched control beverage (MCON; $\downarrow$ ). Error bars are not displayed for the glucose beverage (GLUC; $\Delta$ ) but were comparable in magnitude. * Mean value for BEET was significantly different from that for MCON $(P<0.05)$. 


\section{Insulin sensitivity}

Insulin sensitivity was calculated according the minimal model proposed by Caumo et al. ${ }^{(26)}$. The data were log transformed to reduce the impact of high inter-individual variability in insulin response. No significant differences were observed between the conditions. Insulin sensitivity was $1.05 \times 10^{-5} \mathrm{dl} / \mathrm{kg}$ per min per pmol/1 (95\% CI $0.55,2 \cdot 01)$ for MCON compared with $1.68 \times 10^{-5} \mathrm{dl} / \mathrm{kg}$ per min per pmol/1 (95\% CI 0.86, 3.29) for the BEET condition. Insulin sensitivity in the GLUC condition was $2 \cdot 10 \times 10^{-5} \mathrm{dl} / \mathrm{kg}$ per min per $\mathrm{pmol} / 1$ (95\% CI 1.08, 4.06).

\section{Discussion}

The aim of the present study was to investigate the effects of a beetroot juice on postprandial glucose and insulin concentrations as well as insulin sensitivity and characterise the phytochemicals of this juice. There are two possible confounders of these results that are hereby considered. Acids have been shown to reduce postprandial glucose and insulin concentrations ${ }^{(27,28)}$. There is a small amount of lemon juice present in the beetroot beverage $(<2 \%)$; Leeman et al. ${ }^{(27)}$ showed that acids were required in gram quantities to observe a significant reduction in postprandial glycaemia. The possible confounding of these results by the lemon juice in this beverage may therefore be considered to be negligible. Beetroot juice contains a number of bioactive components including betaxanthins, betanins, flavonoids, phenolic acids ${ }^{(15)}$ and betanin degradation products produced by thermal processing (Table 3). The concentration of betaxanthin was relatively low $(3.29 \mathrm{mg}$ per $225 \mathrm{ml})$, as was the concentration of intact betanins $(48.4 \mathrm{mg}$ per $225 \mathrm{ml}$ ). The betanins were divided into $18.8 \mathrm{mg}$ betanin and $29.5 \mathrm{mg}$ isobetanin. Both flavonoids and phenolic acids were present in moderate concentrations ( $72.7 \mathrm{mg}$ per $225 \mathrm{ml}$ and $55.9 \mathrm{mg}$ per $225 \mathrm{ml}$, respectively). The most abundant compounds in the beetroot juice were betanin degradation products formed, presumably, by thermal processing techniques. These were divided into two predominant compounds: 17-decarboxy-isobetanin (5.08 mg per 225 $\mathrm{ml}$ ); and the orange/yellow pigment; neobetanin (1264 mg per $225 \mathrm{ml}$ ). The much higher CV (among bottles) for the betalain pigments than for the non-betalain types of phenolic compounds indicates that some of the pigment degradation took place after the juice was distributed into the containers, while the non-betalain compounds did not degrade. The contents of nitrate and nitrite were within the ranges previously found for processed beetroot products ${ }^{(29)}$. The nitrite levels were relatively low, indicating that little or no bacterial denitrification had occurred during processing and storage.

There was a similar glycaemic response across the three conditions with the exception of a significantly lower glycaemic response at $5 \mathrm{~min}(P<0.05)$, which persisted, although not significantly, across the proceeding minutes, sufficient to cause a significantly lower glycaemic response $(P<0.05)$ to be detected in the $0-30 \mathrm{~min}$ sAUC for BEET compared with MCON. The moderately attenuated glycaemic response was accompanied by a similarly attenuated early-phase insulin response. A significantly lower insulin response was detected at 15 min for BEET compared with MCON, with further lower responses measured at 5 and $30 \mathrm{~min}$ that did not reach significance $(P=0.08$ and $P=0.09$, respectively). These differences were sufficient to cause significant differences to also be observed in the sAUC segments between 0-30, 0-45 and 0$60 \mathrm{~min}$ for BEET compared with MCON. These results suggest, although not conclusively, that bioactive compounds within beetroot juice may have the potential to help control postprandial glycaemia. Participants were asked to refrain from unusual eating habits, but some participants may still have consumed large quantities of phytochemicals or particularly high quantities of $\mathrm{CHO}$ with their evening meal. This is unlikely to have had a significant impact upon the results since the half-life of polyphenols and betalains is reported to be approximately $5 \mathrm{~h}$ in the blood ${ }^{(30,31)}$.

Törrönen et al. ${ }^{(32)}$ fed fourteen healthy participants a blackcurrant juice beverage containing $50 \mathrm{~g}$ sucrose fortified with crowberry powder, which doubled the polyphenol content compared with the placebo beverage. The crowberry powder was a particularly rich source of anthocyanins, a group within the flavonoid family, and the test beverage provided $293 \mathrm{mg}$ polyphenols per $100 \mathrm{ml}$. The postprandial glycaemic response in the study by Törrönen et al. ${ }^{(32)}$ followed a similar pattern to the present study with no significant differences overall, but a larger (although not significant) glucose and insulin response observed in the early phase (up to $30 \mathrm{~min}$ ) for the control condition compared with the test condition. Törrönen et al. ${ }^{(32)}$ assigned their results to the higher polyphenol content of the test juice, and suggested reduced digestion of sucrose and/or a slower release of glucose in the gut as the likely mechanism(s). The addition of berries, rich in polyphenols, to a sucrose load has previously been shown to attenuate the postprandial glucose and insulin responses in adults ${ }^{(33-35)}$. A number of other studies have also investigated the effect of polyphenol-rich interventions on glucose and/or insulin response in healthy subjects. Overall, a high proportion of these studies show a delayed rise in glucose and/or insulin in the early phase of the postprandial response, which reaches significance in some but not all studies. These studies are summarised in Table $5^{(7,32-45)}$. Some studies have analysed blood taken from venous samples whilst others (including the present study) have utilised capillary sampling. No difference has been observed between capillary and venous sampling, although capillary sampling has previously been suggested to be more accurate ${ }^{(21)}$.

Previous studies have reported polyphenol intakes of 300$800 \mathrm{mg}$ as sufficient to attenuate postprandial glycaemia when consumed alongside $\mathrm{CHO}^{(32,34)}$. The beetroot juice beverage in the present study provided a total of $129 \mathrm{mg}$ of polyphenols together with $1393 \mathrm{mg}$ of betanins and betanin degradation products, in particular $1263 \mathrm{mg}$ neobetanin. The present study thus suggests that betanins (particularly the degradation product neobetanin) and/or nitrate may have comparable effects to phenolic compounds, since the content of flavonoids and phenolic acids contained in beetroot juice is too low to fully account for the observed effects. Neobetanin was identified in the 1980s as the orange/yellow 
Table 5. Review of studies investigating the effects of phytochemicals on postprandial glucose and insulin

\begin{tabular}{|c|c|c|c|c|c|}
\hline Study & Subjects & Treatment & Compound & $\begin{array}{l}\text { Delayed response in } \\
\text { early phase for } \\
\text { glucose or insulin? }\end{array}$ & Significance \\
\hline Cao et al.. & $\begin{array}{l}\text { Eight healthy } \\
\text { elderly women }\end{array}$ & $\begin{array}{l}240 \mathrm{~g} \text { strawberries, } 294 \mathrm{~g} \text { spinach, } \\
300 \mathrm{ml} \text { red wine or } 1250 \mathrm{mg} \text { vitamin C } \\
\text { v. matched control }\end{array}$ & $\begin{array}{l}\text { Various including } \\
\text { anthocyanins } \\
\text { (strawberries) }\end{array}$ & No & $\mathrm{N} / \mathrm{A}$ \\
\hline Johnston et al. ${ }^{(7)}$ & $\begin{array}{l}\text { Nine healthy } \\
\text { adults }\end{array}$ & $\begin{array}{l}400 \mathrm{ml} \text { clear or cloudy apple juice } v \text {. } \\
\mathrm{CHO}-\text { matched control }\end{array}$ & Chlorogenic acid & $\begin{array}{l}\text { Yes (glucose) at } \\
15,30 \mathrm{~min} \text { (clear) } \\
\text { and } 15 \mathrm{~min} \\
\text { (cloudy) }\end{array}$ & $P<0.05$ \\
\hline Kay \& Holub ${ }^{(37)}$ & $\begin{array}{l}\text { Eight healthy } \\
\text { men }\end{array}$ & $\begin{array}{l}100 \mathrm{~g} \text { freeze-dried wild blueberry } \\
\text { powder in } 500 \mathrm{ml} \text { water + high-fat } \\
\text { meal } v \text {. matched placebo control }\end{array}$ & Anthocyanins & No & $\mathrm{N} / \mathrm{A}$ \\
\hline Bryans et al. ${ }^{(38)}$ & $\begin{array}{l}\text { Sixteen healthy } \\
\text { adults; } 4 \mathrm{~m}, 12 \mathrm{f}\end{array}$ & $\begin{array}{l}1 \text { or } 3 \mathrm{~g} \text { black tea }+75 \mathrm{~g} \text { glucose in } \\
150 \mathrm{ml} \text { water } v . \mathrm{CHO} \text {-matched control }\end{array}$ & $\begin{array}{l}\text { Tea polyphenols: } \\
\text { flavan-3-ols, catechins }\end{array}$ & $\begin{array}{l}\text { No. Late-phase } \\
\text { reduction in } \\
\text { glucose }\end{array}$ & $\mathrm{N} / \mathrm{A}$ \\
\hline Wilson et al. ${ }^{(39)}$ & $\begin{array}{l}187 \text { healthy } \\
\text { adults }\end{array}$ & $\begin{array}{l}\text { High- or low-energy } 240 \mathrm{ml} \text { cranberry } \\
\text { juice }+80 \mathrm{mg} \text { vitamin } \mathrm{C} \mathrm{v} \text {. matched } \\
\text { controls }\end{array}$ & Proanthocyanidins & $\begin{array}{l}\text { Yes (glucose) at } \\
30 \text { min } \\
\text { Yes (insulin) up to } \\
60 \text { min }\end{array}$ & No \\
\hline 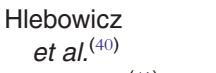 & $\begin{array}{l}\text { Fifteen healthy } \\
\text { adults; } 9 \mathrm{~m}, 6 \mathrm{f}\end{array}$ & $\begin{array}{l}300 \mathrm{~g} \text { rice pudding }+1 \text { or } 3 \mathrm{~g} \\
\text { cinnamon }\end{array}$ & $\begin{array}{l}\text { Methyl } \\
\text { hydroxychalcone }\end{array}$ & $\begin{array}{l}\text { Yes (both) up to } 60 \\
\text { min }\end{array}$ & $\begin{array}{l}\text { No (glucose) } \\
\text { Yes (insulin) }\end{array}$ \\
\hline Josic et al. ${ }^{(41)}$ & $\begin{array}{l}\text { Fourteen } \\
\text { healthy adults; } \\
7 \mathrm{~m}, 7 \mathrm{f}\end{array}$ & $\begin{array}{l}300 \mathrm{ml} \text { green tea together with white } \\
\text { bread and sliced turkey } \mathrm{v} \text {. } \\
\mathrm{CHO} \text {-matched control }\end{array}$ & Flavan-3-ols, catechins & $\begin{array}{l}\text { Yes (glucose) up to } \\
60 \mathrm{~min}\end{array}$ & No \\
\hline Lehtonen et al. ${ }^{(42)}$ & $\begin{array}{l}\text { Ten healthy } \\
\text { men }\end{array}$ & $\begin{array}{l}\text { Sea buckthorn crushed berries }+ \\
\text { yogurt }+50 \mathrm{~g} \text { glucose } v \text {. matched } \\
\text { control }\end{array}$ & Flavonols & $\begin{array}{l}\text { Yes (insulin) at } 30 \\
\text { min }\end{array}$ & $P<0.05$ \\
\hline Törrönen et al. ${ }^{(33)}$ & $\begin{array}{l}\text { Twelve healthy } \\
\text { adults; } 1 \mathrm{~m}, 11 \mathrm{f}\end{array}$ & $\begin{array}{l}150 \mathrm{~g} \text { berry purée (blackcurrants, } \\
\text { cranberries, strawberries, bilberries) } \\
+35 \mathrm{~g} \text { sucrose ( } 800 \mathrm{mg} \text { total } \\
\text { polyphenols) } v \text {. sucrose + } \\
\mathrm{CHO}-\text { matched control }\end{array}$ & Anthocyanins & $\begin{array}{l}\text { Yes (glucose) at } 15 \\
\text { and } 30 \mathrm{~min}\end{array}$ & $\begin{array}{l}P<0.05(15 \\
\min ), P<0.01 \\
(30 \mathrm{~min})\end{array}$ \\
\hline Clegg et al. ${ }^{(43)}$ & $\begin{array}{l}\text { Twelve healthy } \\
\text { adults; } 3 \mathrm{~m}, 9 \mathrm{f}\end{array}$ & $\begin{array}{l}100 \mathrm{~g} \text { blueberries or raspberries in a } \\
\text { pancake meal } v \text {. CHO-matched } \\
\text { control and glucose }\end{array}$ & Anthocyanins & No & $\mathrm{N} / \mathrm{A}$ \\
\hline $\begin{array}{l}\text { Wootton-Beard \& } \\
\text { Ryan }^{(45)}\end{array}$ & $\begin{array}{l}\text { Seventeen } \\
\text { healthy adults; } \\
7 \mathrm{~m}, 10 \mathrm{f}\end{array}$ & $\begin{array}{l}70 \mathrm{ml} \text { beetroot juice + white bread } v \text {. } \\
\mathrm{CHO}-\text { matched control }\end{array}$ & Betalains & $\begin{array}{l}\text { Yes (insulin) at } 15 \\
\text { min }\end{array}$ & $P<0.05$ \\
\hline Törrönen et al. ${ }^{(32)}$ & $\begin{array}{l}\text { Fourteen } \\
\text { healthy adults; } \\
3 \mathrm{~m}, 11 \mathrm{f}\end{array}$ & $\begin{array}{l}300 \mathrm{ml} \text { blackcurrant juice or } \\
\text { blackcurrant juice fortified with } \\
\text { crowberry powder (mainly } \\
\text { anthocyanins } 89 \mathrm{mg} / 100 \mathrm{~g} \mathrm{v.} 178 \mathrm{mg} \\
\text { per } 100 \mathrm{~g} \text { ) }\end{array}$ & Anthocyanins & $\begin{array}{l}\text { Yes (glucose) at } \\
30 \text { min } \\
\text { Yes (insulin) up to } \\
45 \text { min }\end{array}$ & No \\
\hline Törrönen et al. ${ }^{(34)}$ & $\begin{array}{l}\text { Fifteen healthy } \\
\text { adults }\end{array}$ & $\begin{array}{l}150 \mathrm{~g} \text { berry purée }+35 \mathrm{~g} \text { sucrose } v \text {. } \\
\text { sucrose }+\mathrm{CHO} \text {-matched control }\end{array}$ & Anthocyanins & $\begin{array}{l}\text { Yes (glucose) up to } \\
45 \text { min } \\
\text { Yes (insulin) at } 15 \\
\text { min }\end{array}$ & $\begin{array}{l}P<0.05(15 \\
\min ), P<0.01 \\
(15 \min )\end{array}$ \\
\hline Törrönen et al. ${ }^{(35)}$ & $\begin{array}{l}\text { Twenty healthy } \\
\text { women }\end{array}$ & $\begin{array}{l}150 \mathrm{~g} \text { blackcurrant and lingonberry } \\
\text { purée or nectar }+35 \mathrm{~g} \text { sucrose } \mathrm{v} \text {. } \\
\mathrm{CHO}-\text { matched control }\end{array}$ & Anthocyanins & $\begin{array}{l}\text { Yes (glucose) up to } \\
30 \text { min } \\
\text { Yes (insulin) up to } \\
30 \text { min }\end{array}$ & No \\
\hline $\begin{array}{l}\text { Linderborg } \\
\qquad \text { et al. }{ }^{(44)}\end{array}$ & $\begin{array}{l}\text { Ten healthy } \\
\text { men }\end{array}$ & $\begin{array}{l}40 \mathrm{~g} \text { lingonberry powder in yoghurt + } \\
50 \mathrm{~g} \text { glucose } v \text {. CHO-matched control } \\
\text { - lingonberry }\end{array}$ & Flavonol glycosides & $\begin{array}{l}\text { Yes (glucose) } \\
\text { same as berries } \\
\text { Yes (insulin) up to } \\
60 \text { min }\end{array}$ & $\begin{array}{l}\text { No } \\
\text { No }\end{array}$ \\
\hline
\end{tabular}

$\mathrm{N} / \mathrm{A}$, not applicable; $\mathrm{CHO}$, carbohydrate; $\mathrm{m}$, male; f, female.

pigment 5-O- $\beta$-D-glucopyranosylneobetanidin isolated from red beetroot ${ }^{(46-48)}$.

As has been discussed previously, the potential beneficial effects of phytochemicals on the control of postprandial glycaemia may be due to a reduced digestion of glucose, reduced absorption of glucose, stimulation of insulin release or alterations in insulin signalling/sensitivity. The reduced glucose response in the $0-30 \mathrm{~min}$ period following consumption of the beetroot beverage and the persistently reduced insulin response over the first $60 \mathrm{~min}$ also observed following ingestion of the beetroot beverage in the present study suggest that either glucose uptake is blunted, resulting in reduced insulin secretion, or that less insulin is required to restore glucose homeostasis resulting in a reduction in circulating insulin. There is not sufficient evidence presented in the present study to eliminate any potential mechanism, nor are the 
differences observed in the responses sufficient to confirm any of the potential mechanisms, although there is a suggested increase in insulin sensitivity. The insulin sensitivity model that was applied to the data did not reveal any significant differences between the three conditions, which may be largely due to the apparent inter-individual variability of human glycaemic response data. The beetroot condition did result in a higher insulin sensitivity score $(1.68$ (95\% CI $0.86,3.29) \times$ $10^{-5} \mathrm{dl} / \mathrm{kg}$ per min per pmol/l) than the matched control condition $\left(1.05(95 \%\right.$ CI $0.55,2 \cdot 01) \times 10^{-5} \mathrm{dl} / \mathrm{kg}$ per min per pmol/l), which did not approach significance $(P=0 \cdot 24)$.

The high concentration of betalains found in the beetroot juice, particularly betanin degradation products such as neobetanin, suggests that they are the most likely compounds to be responsible for any of the alterations observed. Betalains bear certain structural similarities to the anthocyanin group of polyphenolic compounds, a group which has also been shown to alter postprandial glycaemia ${ }^{(32)}$. Each species of plants contains either betalains or anthocyanins, since the two groups of compounds play exactly the same role in the plant ${ }^{(49)}$. It would therefore not be surprising if these compounds also have similar effects on mammalian physiology.

A review of ninety-seven bioavailability studies showed that ingested polyphenolic compounds reach the low micromolar range in plasma ${ }^{(30)}$. These concentrations were observed for flavanols and catechins, whilst anthocyanins reached only high nanomolar concentrations. There are no studies to date assessing the bioavailability or metabolism of betalain degradation products in humans. Tesoriere et al. ${ }^{(50)}$ examined the absorption, excretion and distribution of native betalains from cactus pear fruit in human LDL. Tesoriere $e t a l{ }^{(50)}$ showed that betanin contained in cactus pear fruit reached a maximum plasma concentration of $0.2 \mu \mathrm{mol} / 1$ after approximately $3 \mathrm{~h}$ following an intake of $16 \mathrm{mg}$, which indicates that betalains reach the plasma in relatively high concentrations compared with anthocyanins. Betalains have a short half-life in the plasma and erythrocytes (about $5 \mathrm{~h})^{(31)}$, which may limit their potential function to processes lasting only a short period such as glucose digestion and absorption. For this potential effect to be prolonged, the desired compounds would need to be ingested in sufficient quantity, at each eating episode containing CHO. The effect of nitrate in this phenomenon cannot be ruled out since polyphenols can mimic nitrate by enhancing the endogenous production of $\mathrm{NO}^{(51)}$. However, the opposite effect of nitrate mimicking polyphenols has yet to be studied.

\section{Conclusions}

This is the first study to investigate the effects of beetroot juice on postprandial glycaemia. The study showed that beetroot juice elicited a significant suppression of postprandial glycaemia in the $0-30 \mathrm{~min}$ sAUC $(P<0.05)$ and postprandial insulinaemia in the $0-30,0-45$ and $0-60$ sAUC $(P<0 \cdot 05)$ when compared with a control beverage matched for $\mathrm{CHO}$ content, which was comparable with that observed using berries in other investigations. HPLC analysis of the beetroot juice revealed that the predominant secondary metabolite (excluding nitrate) in this product is the yellow/orange pigment neobetanin, derived from betanin, as well as significant, but much smaller, amounts of other betalains and polyphenolic compounds. Neobetanin's size and chemical properties (for example, conjugated system) are similar to those of flavonoid polyphenolics such as anthocyanins and it is suggested, therefore, that neobetanin probably contributes to the observed effect, which is similar to effects previously reported for polyphenolic compounds. Insulin sensitivity models applied to the data suggested that insulin sensitivity in the tested cohorts was non-significantly increased with beetroot juice compared with control.

The potential for bioactive phytochemicals to modify substrate metabolism in the postprandial state is a developing area of interest. Reports by Murase et al. ${ }^{(52)}$ on coffee polyphenols (caffeic acid derivatives), Tiwari et al. ${ }^{(53)}$ on the effects of Indian vegetable juices and Linderborg et al. ${ }^{(44)}$ on sea buckthorn have all demonstrated significant effects on glucose and insulin responses. Hyperglycaemia, hyperinsulinaemia and hyperlipidaemia are crucial in the development of CVD, type 2 diabetes and the metabolic syndrome, and whether or not they are able to be modified by dietary components is of significant ongoing interest.

\section{Acknowledgements}

The authors wish to thank Mr Lawrence Mallinson of James White Drinks Ltd for the provision of the beetroot juice for the present study.

Funding for the present study was provided by Oxford Brookes University.

The authors report no conflicts of interest, financial or otherwise.

\section{References}

1. de Bock M, Derraik JGB \& Cutfield WS (2012) Polyphenols and glucose homeostasis in humans. J Acad Nutr Diet 112, 808-815.

2. Hanhineva K, Törrönen R, Bondia-Pons I, et al. (2010) Impact of dietary polyphenols on carbohydrate metabolism. Int J Mol Sci 11, 1365-1402.

3. Rahimi R, Nikfar S, Larijiani B, et al. (2005) A review on the role of antioxidants in the management of diabetes and its complications. Biomed Pharmacother 59, 365-373.

4. Wild S, Roglic G, Green A, et al. (2004) Global prevalence of diabetes: estimates for the year 2000 and projections for 2030. Diabetes Care 27, 1047-1053

5. Popkin BM (2011) Is the obesity epidemic a national security issue around the globe? Curr Opin Endocrinol Diabetes Obes 18, 328-331.

6. Welsch CA, Lachance PA, \& Wasserman BP (1989) Dietary phenolic-compounds: inhibition of $\mathrm{Na}^{+}$-dependent D-glucose uptake in rat intestinal brush-border membrane-vesicles. J Nutr 119, 1698-1704.

7. Johnston KL, Clifford MN \& Morgan LM (2002) Possible role for apple juice phenolic compounds in the acute modification of glucose tolerance and gastrointestinal hormone secretion in humans. J Sci Food Agric 82, 1800-1805.

8. Ishikawa A, Yamashita H, Hiemori M, et al. (2007) Characterization of inhibitors of postprandial hyperglycemia from the leaves of Nerium indicum. J Nutr Sci Vitaminol 53, 166-173.

9. Matsui T, Tanaka T, Tamura S, et al. (2007) $\alpha$-Glucosidase inhibitory profile of catechins and theaflavins. J Agric Food Chem 55, 99-105.

10. Webb AJ, Patel N, Loukogeorgakis S, et al. (2008) Acute blood pressure lowering, vasoprotective, and antiplatelet properties of dietary nitrate via bioconversion to nitrite. Hypertension 51, 784-790. 
11. Lundberg JO, Weitzberg E \& Gladwin MT (2008) The nitratenitrite-nitric oxide pathway in physiology and therapeutics. Nat Rev Drug Discov 7, 156-167.

12. Iijima K, Grantl J, McElroy K, et al. (2003) Novel mechanism of nitrosative stress from dietary nitrate with relevance to gastrooesophageal cancers. Carcinogenesis 24, 1951-1960.

13. Greer FR \& Shannon M (2005) Infant methemoglobinemia: the role of dietary nitrate in food and water. Pediatrics 116, 784-786.

14. Hord NG, Tang Y \& Bryan NS (2009) Food sources of nitrates and nitrites: the physiologic context for potential health benefits. Am J Clin Nutr 90, 1-10.

15. Kujala TS, Vienola MS, Klika KD, et al. (2002) Betalain and phenolic compositions of four beetroot (Beta vulgaris) cultivars. Eur Food Res Tech 214, 505-510.

16. Wootton-Beard PC, Moran A \& Ryan L (2011) Stability of the antioxidant capacity and total polyphenol content of 23 commercially available vegetable juices before and after in vitro digestion as measured by FRAP, DPPH, ABTS and Folin-Ciocalteu methods. Food Res Int 44, 217-224.

17. Wootton-Beard PC \& Ryan L (2011) Short communication: a beetroot juice shot is a significant and convenient source of bioaccessible antioxidants. J Func Foods 3, 329-334.

18. Tsikas D (2000) Simultaneous derivatization and quantification of the nitric oxide metabolites nitrite and nitrate in biological fluids by gas chromatography/mass spectrometry. Anal Chem 72, 4064-4072.

19. Nemzer B, Pietrzkowski Z, Sporna A, et al. (2011) Betalainic and nutritional profiles of pigment-enriched red beet root (Beta vulgaris L.) dried extracts. Food Chem 127, 42-53.

20. Food and Agriculture Organization and Wold Health Organization (1998) Carbohydrates in Human Nutrition: Report of a Joint FAO/WHO Expert Consultation, Rome, 14-18 April 1997. FAO Food and Nutrition Paper 66. Rome: FAO.

21. Brouns F, Björck I, Frayn KN, et al. (2005) Glycaemic index methodology. Nutr Res Rev 18, 145-171.

22. Wolever TMS (2006) The Glycaemic Index: A Physiological Classification of Dietary Carbohydrates. Wallingford: CABI.

23. Perez-Jiménez J, Neveu V, Vos F, et al. (2010) Systematic analysis of the content of 502 polyphenols in 452 foods and beverages: an application of the Phenol-Explorer database. J Agric Food Chem 58, 4959-4969.

24. Baecke JAH, Burema J \& Frijters JER (1982) A short questionnaire for the measurement of habitual physical activity in epidemiological studies. Am J Clin Nutr 36, 936-942.

25. Burattini R, Di Nardo F, Casagrande F, et al. (2009) Insulin action and secretion in hypertension in the absence of metabolic syndrome: model-based assessment from oral glucose tolerance test. Metab Clin Exp 58, 80-92.

26. Caumo A, Bergman RN \& Cobelli C (2000) Insulin sensitivity from meal tolerance tests in normal subjects: a minimal model index. J Clin Endocrinol Metab 85, 4396-4402.

27. Leeman M, Östman E \& Björck I (2005) Vinegar dressing and cold storage of potatoes lowers postprandial glyceamic and insulinaemic responses in healthy subjects. Eur J Clin Nut 59, 1266-1271.

28. Shahidi F, McDonald J, Chandrasekara A, et al. (2008) Phytochemicals of foods, beverages and fruit vinegars. Chemistry and health effects. Asia Pac J Clin Nutr 17, 380-382.

29. Tamme T, Reinik M, Püssa T, et al. (2010) Dynamics of nitrate and nitrite content during storage of home-made and small-scale industrially produced raw vegetable juices and their dietary intake. Food Addit Contam Part A Chem Anal Control Expo Risk. Assess 27, 487-495.

30. Manach C, Williamson G, Morand C, et al. (2005) Bioavailability and bioefficacy of polyphenols in humans. I. Review of 97 bioavailability studies. Am J Clin Nutr 81, 230S-242S.

31. Tesoriere L, Allegra M, Butera D, et al. (2005) Distribution of betalain pigments in red blood cells after consumption of cactus pear fruits and increased resistance of the cells to ex vivo induced oxidative haemolysis in humans. J Agric Food Chem 53, 1266-1270.

32. Törrönen R, McDougall G, Dobson G, et al. (2012) Fortification of blackcurrant juice with crowberry: impact on polyphenol composition, urinary phenolic metabolites, and postprandial glycemic response in healthy subjects. J Func Foods 4, 746-756.

33. Törrönen R, Sarkkinen E, Tapola N, et al. (2010) Berries modify the postprandial plasma glucose response to sucrose in healthy subjects. Br J Nutr 103, 1094-1097.

34. Törrönen R, Sarkkinen E, Niskanen T, et al. (2012) Postprandial glucose, insulin and glucagon-like peptide 1 responses to sucrose ingested with berries in healthy subjects. Br J Nutr 107, 1445-1451.

35. Törrönen R, Kohlemeinen M, Sarkkinen E, et al. (2012) Postprandial glucose, insulin and free fatty acid responses to sucrose consumed with blackcurrants and lingonberries in healthy women. Am J Clin Nutr 96, 527-533.

36. Cao G, Russell RM, Lischner N, et al. (1998) Serum antioxidant capacity is increased by consumption of strawberries, spinach, red wine or vitamin C in elderly women. J Nutr 128, 2383-2390.

37. Kay CD \& Holub BJ (2002) The effect of wild blueberry (Vaccinium angustifolium) consumption on postprandial serum antioxidant status in human subjects. Br J Nutr 88, 389-397.

38. Bryans JA, Judd PA \& Ellis PR (2007) The effect of consuming instant black tea on postprandial glucose and insulin concentrations in healthy humans. J Am Coll Nutr 26, 471-477.

39. Wilson T, Singh AP, Vorsa N, et al. (2008) Human glycaemic response and phenolic content of unsweetened cranberry juice. J Med Food 11, 46-54.

40. Hlebowicz J, Hlebowicz A, Lindstedt S, et al. (2009) Effects of 1 and $3 \mathrm{~g}$ cinnamon on gastric emptying, satiety and postprandial blood glucose, insulin, glucose-dependent insulinotropic polypeptide, glucagon-like peptide 1 and ghrelin concentrations in healthy subjects. Am J Clin Nutr 89, 815-821.

41. Josic J, Olsson AT, Wickeberg J, et al. (2010) Does green tea affect postprandial glucose, insulin and satiety in healthy subjects: a randomised controlled trial? Nutr J 9, 63-71.

42. Lehtonen HM, Järvinen R, Linderborg K, et al. (2010) Postprandial hyperglycemia and insulin response and affected by sea buckthorn (Hippophaë rhamnoides ssp. Turkestanica) berry and its ethanol-soluble metabolites. Eur J Clin Nutr 64, 1465-1471.

43. Clegg ME, Pratt M, Meade CM, et al. (2011) The addition of raspberries and blueberries to a starch-based food does not alter the glycaemic response. Br J Nutr 106, 335-338.

44. Linderborg KM, Lehtonen HM, Järvinen R, et al. (2012) The fibres and polyphenols in sea buckthorn (Hippophae rhamnoides) extraction residues delay postprandial lipemia. Int J Food Sci Nutr 63, 483-490.

45. Wootton-Beard PC \& Ryan L (2012) Potential influence of phytochemicals from beetroot juice on postprandial glycaemia. Proc Nutr Soc 71, E92.

46. Alard D, Wray V, Grotjahn L, et al. (1985) Neobetanin - isolation and identification from Beta-vulgaris. Phytochemistry 24, 2383-2385.

47. Wyler H (1986) Neobetanin - a new natural plant constituent. Phytochemistry 25, 2228-2238.

48. Strack D, Engel U \& Wray V (1987) Neobetanin - a new natural plant constituent. Phytochemistry 26, 2399-2400.

49. Stafford HA (1994) Anthocyanins and betalains: evolution of the mutually exclusive pathways. Plant Science 101, 91-98.

50. Tesoriere L, Allegra M, Butera D, et al. (2004) Absorption, excretion, and distribution of dietary antioxidant betalains in LDLs: potential health effects of betalains in humans. Am J Clin Nutr 80, 941-945.

51. Volk J, Gorelik S, Granit R, et al. (2009) The dual function of nitrate under stomach conditions is modulated by reducing compounds. Free Rad Biol Med 47, 496-502.

52. Murase T, Yokoi Y, Misawa K, et al. (2012) Coffee polyphenols modulate whole-body substrate oxidation and suppress postprandial hyperglycaemia, hyperinsulinaemia and hyperlipidaemia. Br J Nutr 107, 1757-1765.

53. Tiwari AK, Reddy KS, Radhakrishnan J, et al. (2011) Influence of antioxidant rich fresh vegetable juices on starch induced postprandial hyperglycaemia in rats. Food Func 2, 521-528. 